\title{
Science Process Skills Acquired by Senior Secondary School Chemistry Students in Quantitative Analysis in Enugu Education Zone, Nigeria
}

\author{
${ }^{1}$ Florence Obiageli Ezeudu, ${ }^{2}$ Anselem Abonyi Ugwuanyi and ${ }^{1}$ Ameh Rachael Folake \\ ${ }^{1}$ Department of Science Education, University of Nigeria, Nsukka, Enugu State, Nigeria \\ ${ }^{2}$ Department of Chemistry, Federal College of Education, Osiele, Abeokuta, Ogun State, Nigeria \\ anselem.abonyiugwuanyi@gmail.com,+2348036754149
}

\begin{abstract}
The study was aimed at ascertaining the science process skills acquired by senior secondary school chemistry students in quantitative analysis in Enugu Education Zone of Nigeria. The sample was made up of 60 Secondary School Students (SSSIII) from 6 secondary schools in Enugu Education Zone of Enugu State. The design for the study was descriptive survey. The science process skills investigated were observing experimenting, controlling variables, measuring, recording, communicating and inference using quantitative analysis chemistry practical activities. The instrument for data collection was the Practical Chemistry Skills Rating Scale (PCSRS). The instrument contained 27 quantitative analysis items. Data collected were interpreted using mean, standard deviation, Z-test and ANOVA. It was found that of the 7 skills investigated, students had poor level of acquisition in four science process skills controlling variables, recording, communication and inference. Gender and school type had no significant influence whereas school location had significant influence in favour of urban. Among others, it was recommended that pedagogical inspectors, principals and school administrators should be strict on the maximum use of the science laboratory by science teachers.
\end{abstract}

Key words: Chemistry students, science process skills, senior secondary school, quantitative analysis, Nigeria, administrators

\section{INTRODUCTION}

Chemistry is a branch of science which deals with study of matter, its structure, composition, prosperities and changes it undergoes. Chemistry aims at helping learners to acquire appropriate skills, abilities and competencies that would enable them contribute to the development of society. Chemistry cannot be isolated from our lives, since, human beings have always been in contact with chemical substances and technological products such as cosmetics, drugs, detergents/soaps and fertilizer among others. Chemistry has contributed greatly towards providing our basic needs and improving the quality of life. In recognition of important of Chemistry to the society, research for more effective approach for the teaching and learning of science that will enhance the acquisition of process skills have been persisted over the years. This is because the acquisitions of science process skills offer the basis for scientific inquiry, development of intellectual skills and attitudes that are needed to learn concept. Ozgelen (2012) defined science process skills as abilities, potentials as well as all the technical "know how" which can be developed in a child and which can be employed in carrying out mental and physical operation in science. Aydogdu (2015) described science process skills as mental and physical abilities and competencies which serve as tools needed for the effective study of science and technology as well as problem solving for individual and societal development. Acquisition of these skills is enhanced by the use of experimental method of teaching which involves child's active involvement in activities. The shift from the teacher-centered method of teaching science to child-centered activity based method which encourages and develops in the child the spirit of inquiry; an attempt to make students fully aware as well as understand the ways scientists work and also the equipping and preparing students for their possible careers in science and technology led to the development of process skills (Igbonegwu and Okonkwo, 2011).

The American Association for the Advancement of Science (AAAS., 1967) classified the science process skills into fifteen. These are observing, measuring, classifying, communicating, predicting, inferring, using number, using space/time relationship, questioning, controlling variables, hypothesizing, defining operationally, formulating models, designing experiment and interpreting data. According to Ango (2011), science

Corresponding Author: Anselem Abonyi Ugwuanyi, Department of Chemistry, Federal College of Education, Osiele, Abeokuta, Ogun State, Nigeria, anselem. abonyiugwuanyi@gmail.com, +2348036754149 
process skills can be classified into two categories as basic and integrated process skills. The basic (simpler) process skill provide a foundation for learning the integrated (more complex) skills. Basic since processes are vital for science learning and concept formation at the primary and junior secondary school levels. More difficult and integrated science process skills are more appropriate at the senior secondary and tertiary school levels for the formation of models, experimenting and inferring. Hence, both basic and integrated science process skills are relevant and appropriate at the senior secondary school level in Nigeria. This study identified level of acquisition of 7 out of the 15 science process skills. These comprised of 5 basic science process skills (observation, measuring, recording, communication and inferring skills) and (2) integrated science process skill (controlling variables and experimenting).

Since, process skills acquisition has significance influence on student's practical activities at senior secondary school level where students are required to be evaluated on practical activities as one aspect of the nine papers written in the final examination. This practical test is designed to develop and test the three aspect of the student's intellectual development, cognitive, affective and psychomotor skills. This practical is introduced late and students have to acquire these practical skills in few months to write WAEC and NECO examinations. The late introduction of training in the psychomotor skills at the SSIII may be the cause of poor student's achievement in chemistry practical at SSSIII as reported by WAEC Chief Examiner's Report 2014. Chemistry students will have problem of acquiring these practical skills in short period to write the final examination. This might affect the overall achievement of students in $O^{\prime}$ level chemistry practical. Some reviewed literatures have shown that students have low level of acquisition of science process skills in some skills (Aydogdu, 2015).

Student's acquisition of science skills in practical work can be influenced by other factors such as gender, school location, school type in science generally on the acquisition of science process skills in particular. Some researchers have reported the place of gender in acquisition of science process skills in sciences. For example, Akinbobola and Afolabi (2012) and Muhammad (2014) submitted that gender had no significant influence on acquisition of science process skills among the secondary school students in biology. But Ugwu (2009) and Njoku and Jacks (2011) found out that gender had significant effect on acquisition of process skills. By location, according to Yusuf and Adigun (2010) and Akinbobola (2008), urban students outperformed their rural counterparts in chemistry achievement test. In contrary, Ezeudu and Obi-Theresa (2013) and Yusuf and
Adigun (2010) found no significant difference between urban and rural schools. Regarding the influence of school type on student's achievement in science, literature revealed that females benefited more in single schools than in co educational schools (Jacks, 2013). In contrary, Yusuf and Adigun (2010) noted that students in all male schools performed better on some skills acquisition followed by those in co-educational schools and least was female schools. Ugwu (2009) and Yusuf and Adigun (2010) found that school type has no influence on practical skills acquisition. These factors which affect science process skills could also affect student's achievement in chemistry practical. It is therefore, necessary to ascertain the science process skills acquired by senior secondary school students in chemistry practical activities and to suggest ways of improving the student's acquisition of the skills.

Statement of problem: Science process skills are useful in science and non-science situations. Science process skills are the working behaviours of the scientists and technologists. Process skills are very fundamental to science which allows students to conduct investigations and reach conclusions but there is still a serious educational gap in this area both in bringing these skills into the classroom and in the training of teachers to use them effectively. Both basic and integrated science process skills are relevant and appropriate for learning science subjects, especially, chemistry practical at senior secondary school level in Nigeria. However, there is consistent poor achievement of students in chemistry practical at senior secondary school level. Achievement in chemistry practical is related to the acquisition of science process skills and if the acquisition of these skills is low, achievement will consequently be low. Most importantly, the acquisition of these skills is through laboratory practical activities. Could this study achievement in chemistry practical be as a result of the lack of the acquisition of science process skills by Chemistry students during practical activities? Hence, the problem of the study is to identify the level of science process skills acquired by senior secondary school Chemistry students. Specifically, this study will involve identification of the influence of gender, school type and school location on chemistry student's level of acquisition of science process skills in practical chemistry.

Objective of the study: The main objective of the study is to identify science process skills acquired by senior secondary school chemistry students. Specifically, the study intends to: 
- Ascertain the level of science process skills acquired by students in quantitative analysis practical chemistry

- Ascertain the influence of gender on level of science process skills acquired by students in quantitative analysis practical chemistry

- Ascertain the influence of school type on level of science process skills acquired by students in quantitative analysis practical chemistry

- Ascertain the influence of school location on level of science process skills acquired by students in quantitative analysis practical chemistry

Research question: What is the level of science process skills acquired by students in quantitative analysis practical Chemistry? What is the influence of gender on level of science process skills acquired by students in quantitative analysis practical Chemistry? What is the influence of school type on level of science process skills acquired by students in quantitative analysis practical Chemistry? What is the influence of school location on level of science process skills acquired by students in quantitative analysis practical Chemistry?

Hypothesis: There is no statistically significant difference between the mean scores of male and female on level of science process skills acquired by students in practical Chemistry. There is no statistically significant difference in the mean scores of male, female and co-educational school students on level of science process skills acquired by students in practical Chemistry. There is no statistically significant difference in the mean scores of urban and rural students on level of science process skills acquired by students in practical Chemistry.

\section{MATERIALS AND METHODS}

The design of the study was a descriptive survey research design. The area of the study was Enugu Education Zone of Enugu State. The population of the study consisted of 802 Senior Secondary three (SSIII) chemistry students in the 27 schools in Enugu Education Zone in 2014/2015 academic year (Statistics Office PPSMB A sample size of 60 SSIII Chemistry students from six schools was drawn. The research adopted a multi-stage sampling technique. The multi-stage sampling technique consisted of number of distinct stages. The 1 st involves purposive sampling which was used to select the 6 schools required. The instrument for data collection for this study was the Practical Chemistry Skills Rating Scale (PCSRS). The instrument consisted of 27 Quantitative Analysis (QTA) items adapted from
(Ugwu, 2009). The raters/teachers rated the students using scale points of: Very Good (VG)-4 points Good (G)-3 points, Fair (F)-2 points and Poor (P)-1 point. The instrument was validated by three experts in measurement and evaluation and two subject specialists. The trial testing of the instrument was carried out on a representative sample of 10 SS III Chemistry students by three Chemistry teachers that the researchers trained on the rating of the items. These students were randomly selected from 2 secondary schools from Nsukka Education Zone of Enugu state. Kendall's co-efficient of concordance showed reliability value of 0.79 which was adjudged to be high. The internal consistency reliability was estimated using Cronbah's alpha which yielded a value of 0.84 and this was adjudged to be high. Mean and standard deviation were used to interpret the research questions. A mean score of 2.5 and above on a skill were considered to be high level of acquisition of the skills while a mean score of below 2.5 was considered as indicator of low level of acquisition of the skills. Z-test and ANOVA were used to test the hypothes at 0.05 level of significance.

\section{RESULTS AND DISCUSSION}

Research question 1: What is the level of science process skills acquired by students in quantitative analysis practical Chemistry?

Table 1 shows that, students generally have low level of acquisition on skills 3, 4, 5 and 7. However, students have high level of acquisition of other skills as shown in Table 1 .

Research question 2: What is the influence of gender on level of science process skills acquired by students in quantitative analysis practical Chemistry?

Table 2 shows that the male students had high level of acquisition of science process skills on quantitative analysis than those of female students as can be deduced from their high overall mean score of 2.72 when compared to 2.56 of the female students. However, hypothesis one

\begin{tabular}{lccccc}
$\begin{array}{l}\text { Table 1: Mean and Standard Deviation (SD) of clusters of quantitative } \\
\text { analysis scores on level of science process skills acquired by } \\
\text { chemistry students in practical activities }\end{array}$ \\
$\begin{array}{l}\text { No. of } \\
\text { items }\end{array}$ & $\begin{array}{c}\text { No. of } \\
\text { students }\end{array}$ & $\overline{\mathrm{X}}$ & $\mathrm{SD}$ & Levels \\
\hline $\begin{array}{l}\text { Process } \\
\text { skills }\end{array}$ & 4 & 60 & 2.97 & 0.53 & High \\
\hline Observation & 6 & 60 & 2.85 & 0.44 & High \\
Experimenting & 6 & 60 & 2.43 & 1.09 & High \\
Controlling variables & 6 & 60 & 2.87 & 0.49 & High \\
Measuring & 4 & 60 & 2.31 & 0.98 & Low \\
Recording & 3 & 60 & 2.46 & 0.89 & Low \\
Communication & 3 & 60 & 2.47 & 0.87 & Low \\
Inference & 1 & & & &
\end{tabular}


was tested to see, if this difference is significant. Both male and female students had low level of acquisition on skills $3,5,6$ and 7 and high level on skills 1,2 and 4.

Research question 3: What is the influence of school type on level of science process skills acquired by students in practical Chemistry?

Table 3 reveals that male school students had high level of acquisition of science process skills followed by the female schools and co-educational schools. These can be deduced from their overall mean scores of $2.80,2.74$ and 2.71 , respectively. However, hypothesis 2 was tested to see if this difference is significant. Male school students had low level of acquisition in skill 3. Female school students had low level of acquisition in skill 7 and co-educational school students had low level in 3 and 7. Male school students had high level of acquisition in skills 1-7. The female school students had high level of acquisition in skills 1-6. The

Table 2: Mean and Standard Deviation (SD) of clusters of quantitative analysis scores on level of science process skills acquired by male and female Chemistry students in practical activities

\begin{tabular}{lccccccc}
\hline \multicolumn{1}{c}{$\begin{array}{l}\text { Process } \\
\text { skills }\end{array}$} & $\begin{array}{c}\text { No. of } \\
\text { items }\end{array}$ & $\begin{array}{c}\overline{\mathrm{X}} \\
\text { male }\end{array}$ & SD & Levels & $\begin{array}{c}\overline{\mathrm{X}} \\
\text { female }\end{array}$ & SD & Levels \\
\hline Observation & 4 & 3.15 & 0.52 & High & 2.79 & 0.54 & High \\
Experimenting & 6 & 2.98 & 0.43 & High & 2.72 & 0.45 & High \\
Controlling variables & 6 & 2.46 & 1.07 & Low & 2.40 & 1.11 & Low \\
Measuring & 4 & 3.00 & 0.46 & High & 2.74 & 0.52 & High \\
Recording & 3 & 2.48 & 0.90 & Low & 2.40 & 0.86 & Low \\
Communication & 3 & 2.49 & 0.98 & Low & 2.44 & 0.79 & Low \\
Inference & 1 & 2.49 & 0.81 & Low & 2.45 & 0.93 & Low \\
Overall mean & & 2.72 & 0.74 & High & 2.56 & 0.68 & High \\
\hline
\end{tabular}

co-educational students had high level of acquisition in skills $1,2,4,5$ and 6 . However, hypothesis 2 was tested to see if this difference is significant.

Research question 4: What is the influence of school location on level science process skills acquired by students in practical Chemistry?

Table 4 shows that students from urban location had high level of acquisition of the science process skills than those from rural location as can be deduced from their high overall mean score of 2.93 when compared to 2.56 of the rural location. Urban location had low level of acquisition on skills 7 and high level on skills 1-6. Rural location had low level of acquisition on skills 3 and 7 with high level on skills 1-6. However, hypothesis 3 was tested to see if this difference is significant.

- $\mathrm{H}_{1}$ : there is no statistically significant difference between the mean scores of male and female on level of science process skills acquired by students in practical Chemistry

From Table 5, $Z$ calculated value in respect of gender for students mean process skills scores in quantitative analysis items is seen to be 1.20 while the $Z$-critical value at 0.05 level of significance is 1.96 Thus, the Z-calculated value is less than the $Z$-critical value. The null hypothesis $\left(\mathrm{H}_{0}\right)$ is therefore, accepted. To this effect the researcher concluded that there is no statistically significant influence of gender on student's level of acquisition of science process skills in practical chemistry.

Table 3: Mean and Standard Deviation (SD) of clusters of quantitative analy sis scores on level of science process acquired by chemistry students in practical activities by school type

\begin{tabular}{lccccccccccc}
\hline Process skills & No. of items & $\bar{X}$ male & SD & Levels & $\bar{X}$ females & SD & Levels & $\bar{X}$ coeduc & SD & Levels \\
\hline Observation & 4 & 3.09 & 0.41 & High & 2.86 & 0.65 & High & 2.96 & 0.55 & High \\
Experimenting & 6 & 2.96 & 0.51 & High & 2.83 & 0.38 & High & 2.76 & 0.43 & High \\
Controlling variables & 6 & 2.45 & 1.15 & Low & 2.50 & 0.97 & High & 2.34 & 1.15 & Low \\
Measuring & 4 & 2.92 & 0.44 & High & 2.82 & 0.61 & High & 2.87 & 0.52 & High \\
Recording & 3 & 2.82 & 0.60 & High & 2.79 & 0.48 & High & 2.82 & 0.67 & High \\
Communication & 3 & 2.82 & 0.81 & High & 2.97 & 0.54 & High & 2.79 & 0.52 & High \\
Inference & & 2.54 & 0.81 & High & 2.43 & 0.87 & Low & 2.44 & 0.91 & Low \\
Overall mean & & 2.800 & 0.62 & High & 2.74 & 0.64 & High & 2.71 & 0.68 & High \\
\hline
\end{tabular}

Table 4: Mean and Standard Deviation (SD) of clusters of quantitative analysis scores on level of science process skills acquired by urban and rural Chemistry students in practical activities

\begin{tabular}{|c|c|c|c|c|c|c|c|}
\hline Process skills & No. of items & $\overline{\mathrm{X}}$ urban & $\mathrm{SD}$ & Levels & $\overline{\mathrm{X}}$ rural & $\mathrm{SD}$ & Levels \\
\hline Observation & 4 & 3.11 & 0.44 & High & 2.83 & 0.62 & High \\
\hline Experimenting & 6 & 3.15 & 0.42 & High & 2.55 & 0.46 & High \\
\hline Controlling variables & 6 & 2.58 & 0.98 & High & 2.28 & 1.20 & Low \\
\hline Measuring & 4 & 3.20 & 0.45 & High & 2.51 & 0.53 & High \\
\hline Recording & 3 & 2.86 & 0.55 & High & 2.76 & 0.61 & High \\
\hline Communication & 3 & 3.16 & 0.48 & High & 2.56 & 0.52 & High \\
\hline Inference & 1 & 2.48 & 0.75 & Low & 2.46 & 0.99 & Low \\
\hline Overall mean & & 2.93 & 0.58 & High & 2.56 & 0.70 & High \\
\hline
\end{tabular}


Table 5: Z-test comparison of the mean scores of male and female chemistry students on the level of science process skills acquired in quantitative analysis practical activities

\begin{tabular}{lllllll}
\hline Gender & $\mathrm{N}$ & Mean & SD & Z-cal & Z-critical & Decision \\
Male & 30 & 2.85 & 0.61 & 1.20 & 1.96 & Accepted \\
Female & 30 & 2.65 & 0.68 & & & \\
\hline
\end{tabular}

Table 6: ANOVA result of mean process skills scores of male, female and co-educational school chemistry students chemistry students in quantitative analysis practical activities

\begin{tabular}{|c|c|c|c|c|c|c|}
\hline $\begin{array}{l}\text { Source of } \\
\text { variable }\end{array}$ & $\mathrm{df}$ & $\begin{array}{l}\text { Sum of } \\
\text { squares }\end{array}$ & $\begin{array}{l}\text { Mean } \\
\text { squares }\end{array}$ & F-cal & F-critical & Decision \\
\hline Between group & 2 & 5.76600 & 2.883 & 1.51 & 3.15 & Accepted \\
\hline Within group & 57 & 108.682 & 1.907 & & & \\
\hline Total & 59 & 114.448 & 4.790 & & & \\
\hline
\end{tabular}

Table 7: Z-test comparison of mean scores of urban and rural chemistry students on level of science process skills acquired in quantitative analysis practical activities

\begin{tabular}{lllllll}
\hline Location & $\mathrm{N}$ & Mean & SD & Z-cal & Z-critical & Decision \\
Urban & 30 & 2.93 & 0.58 & 2.20 & 1.96 & Rejected \\
Rural & 30 & 2.56 & 0.70 & & & \\
\hline
\end{tabular}

- $\mathrm{H}_{2}$ : there is no statistically significant difference in the mean scores of male, female and co-educational school students on level of science process skills acquired by students in practical Chemistry

From Table 6 , the calculated F-value is 1.51 while the critical value of $F$ with 2 and $57^{\circ}$ of freedom at 0.05 level of significant is 3.15 . Thus, the calculated F-value of 1.51 is less than the F-critical value of 3.15. Consequently, the null hypothesis of no significant difference in the mean process skills scores of male, female and co-education students in in quantitative analysis practical activities rejected.

- $\mathrm{H}_{3}$ : there is no statistically significant difference in the mean scores of urban and rural students on level of science process skills acquired by students in practical chemistry

From Table 7, Z-calculated value in respect of school location for students mean process skills scores in quantitative analysis item is seen to be 2.20 while the $Z$-critical value at 0.05 level of significance is 1.96 . Thus, $Z$-calculated value is greater than the $Z$-critical value. The null hypothesis $\left(\mathrm{H}_{0}\right)$ is therefore, rejected.

The study was aimed at ascertaining the science process skills acquired by senior secondary school chemistry students in quantitative analysis in Enugu Education Zone of Nigeria. The results of the study showed that the mean scores of controlling variables and inference skills were poorly acquired by the students. This finding is in agreement with some other research findings (Aydogdu, 2015) which showed that the level of acquisition of science process skills by the students is low. The result also showed that the male students had higher level of acquisition of the skills than the female counterparts. Therefore, there is no statistically significant influence of gender on level of process skills acquired by chemistry students in quantitative analysis. This finding is in agreement with the views of Akinbobola and Afolabi (2012) and Muhammad (2014) who found that gender had no significant influences on science process skills acquisition. But this in contrary to Abonyi (2015) and Njoku and Jacks (2011) found out that gender had significant effect on acquisition of process skills. The study showed that there are some differences in the overall mean process skills scores of male, female and co-educational school students. This revealed that school type influences practical chemistry skills acquisition. The finding of the study showed that there is no statistically significant influence of school type on the level of science process skills acquired by the Chemistry students in practical Chemistry. Hence, the result agrees with the views of Jack (2013) who found that there was significant influence of school type of student's acquisition of science process skills. It disagrees with Ugwu (2009) and Yusuf and Adigun (2010) who found that school type has no influence on practical skills acquisition. The study also revealed that urban students had higher level of acquisition of the skills than the rural in quantitative analysis. Therefore, there is a statistically significant influence of school location on level of science process skills acquired by chemistry students in practical chemistry. The finding is in line with the findings of Yusuf and Adigun (2010) and Akinbobola (2008) who found significant difference between urban and rural schools. Who found that urban students performed better than the rural students. In contrary, Ezeudu and Obi-Theresa (2013) and Yusuf and Adigun (2010) who found no significant influence of school location on students acquisition of science process skills.

\section{CONCLUSION}

Conclusively, students had poor level of acquisition of the science process skills except for observation, experimenting and measuring in the practical chemistry activities. There is no statistically significant difference between the mean scores of male and female on the level of science process skills acquired by chemistry students in practical chemistry. There is no statistically significant difference in the mean scores of male, female and co-educational school students on the level of science process skills acquired by chemistry students in practical chemistry. There is a statistically significant difference between mean scores of urban and rural students on the level of science process skills acquired by chemistry students in practical chemistry. 


\section{RECOMMENDATIONS}

In order to solve the problems of student's poor level of acquisition of science process skills, the following recommendations were made. The government should put as a pre-condition a well-equipped science laboratory for approval of any secondary school in the country. Pedagogical inspectors, principals and school administrators should be strict on the maximum use of the science laboratory by science teachers. More qualified science teachers should be employed and evenly posted, since, they are in a better position to use the practical activities in promoting student's level of acquisition of skills in practical chemistry in every school.

\section{ACKNOWLEDGEMENT}

The researchers wish to acknowledge the effort of the study participants that made this study successful .

\section{REFERENCES}

AAAS., 1967. Science a Process Approach. Xerox Corporation, Norwalk, Connecticut, USA.,.

Abonyi, U.A., 2015. Science process skills acquired by senior secondary school students in Enugu educational zone. M.Ed Thesis, University of Nigeria Nsukka, Nsukka, Nigeria.

Akinbobola, A.O. and F.O. Afolabi, 2012. Creating and sustaining acting learning in physics classroom. Eur. J. Bus. Soc. Sci., 1: 11-24.

Akinbobola, A.O., 2008. Effect of Physics practical on students' process skills acquisition in Abuja municipal area council. M.Ed Thesis, University of Nigeria Nsukka, Nsukka, Nigeria.
Ango, M.L., 2011. Needed Science Process Skills as Foundation for Effective Technology Education for National Development?. In: Technology Education for National Development, Awotunde, P.O. (Ed.). National Association of Teachers of Technology, Jos, Nigeria, pp: 92-104.

Aydogdu, B., 2015. The investigation of science process skills of science teachers in terms of some variables. Educ. Res. Rev., 10: 582-594.

Ezeudu, F.O. and N. Obi-Theresa, 2013. Effect of gender and location on students achievement in Chemistry in secondary schools in Nsukka local governmentarea of Enugu state, Nigeria. Res. Humanities Soc. Sci., 3: $50-55$.

Jack, G.U., 2013. The influence of identified student and school variables on students' science process skills acquisition. J. Educ. Pract., 4: 16-22.

Muhammad, B.A., 2014. An evaluation of the efficacy of conceptual instructional method of teaching practical chemistry: A case study of secondary schools in Zaria education Zone of Kaduna State, Nigeria. Afr. J. Educ. Technol., 4: 112-118.

Njoku, Z.C. and A.N. Jacks, 2011. Identification of difficult science process skill in Physics practical activities amongst advanced Physics student. Afr. J. Sci. Technol. Math. Educ., 1: 65-68.

Ozgelen, S., 2012. Students' science process skills within a cognitive domain framework. Eurasia J. Math. Sci. Technol. Educ., 8: 283-292.

Ugwu, A.N., 2009. Development and validation of an instrument for the assessment of science process skills acquisition in practical chemistry. Ph.D Thesis, University of Nigeria Nsukka, Nsukka, Nigeria.

WAEC., 2014. Chief examiner's report on student's performance in senior secondary school certificate chemistry examination. West African Examination Council, Gwagwalada, Nigeria.

Yusuf, M.A. and J.T. Adigun, 2010. The influence of school sex, location and type on student's academic performance. Intl. J. Educ. Sci., 2: 81-85. 